\title{
Hominin responses to environmental changes during the Middle Pleistocene in central and southern Italy
}

\author{
R. Orain ${ }^{1}$, V. Lebreton ${ }^{1}$, E. Russo Ermolli ${ }^{2}$, A.-M. Sémah ${ }^{1,3}$, S. Nomade ${ }^{4}$, Q. Shao ${ }^{1}$, J.-J. Bahain ${ }^{1}$, \\ U. Thun Hohenstein ${ }^{5}$, and C. Peretto \\ ${ }^{1}$ Département de Préhistoire, Muséum National d'Histoire Naturelle, CNRS - UMR7194, 1 rue René Panhard, \\ 75013 Paris, France \\ ${ }^{2}$ Università di Napoli Federico II, corso Umberto I, 80138 Napoli, Italy \\ ${ }^{3}$ Institut de Recherche pour le Développement, LOCEAN - Paléoproxus, CNRS - UMR7159, 32 avenue Henri Varagnat, \\ 93143 Bondy Cedex, France \\ ${ }^{4}$ Laboratoire des Sciences du Climat et de l'Environnement, Institut Pierre Simon Laplace, CNRS-CEA-UVSQ - UMR8212, \\ Avenue de la Terrasse, 91190 Gif-sur-Yvette Cedex, France \\ ${ }^{5}$ Dipartimento delle Risorse Naturali e Culturali, Università di Ferrara, C. so Ercole I d'Este 32, 44100 Ferrara, Italy
}

Correspondence to: R. Orain (ronan.orain@edu.mnhn.fr)

Received: 28 September 2012 - Published in Clim. Past Discuss.: 23 October 2012

Revised: 14 January 2013 - Accepted: 18 February 2013 - Published: 14 March 2013

\begin{abstract}
The palaeobotanical record of early Palaeolithic sites from Western Europe indicates that hominins settled in different kinds of environments. During the "mid-Pleistocene transition (MPT)", from about 1 to $0.6 \mathrm{Ma}$, the transition from 41- to 100-ka dominant climatic oscillations, occurring within a long-term cooling trend, was associated with an aridity crisis which strongly modified the ecosystems.

Starting from the MPT the more favourable climate of central and southern Italy provided propitious environmental conditions for long-term human occupations even during the glacial times. In fact, the human strategy of territory occupation was certainly driven by the availabilities of resources. Prehistoric sites such as Notarchirico (ca. 680-600 ka), La Pineta (ca. 600-620 ka), Guado San Nicola (ca. 380-350 ka) or Ceprano (ca. 345-355 ka) testify to a preferential occupation of the central and southern Apennines valleys during interglacial phases, while later interglacial occupations were oriented towards the coastal plains, as attested by the numerous settlements of the Roma Basin (ca. $300 \mathrm{ka}$ ). Faunal remains indicate that human subsistence behaviours benefited from a diversity of exploitable ecosystems, from semi-open to closed environments. In central and southern Italy, several palynological records have already illustrated the regionaland local-scale vegetation dynamic trends. During the Middle Pleistocene climate cycles, mixed mesophytic forests
\end{abstract}

developed during the interglacial periods and withdrew in response to increasing aridity during the glacial episodes. New pollen data from the Boiano Basin (Molise, Italy) attest to the evolution of vegetation and climate between MIS 13 and 9 (ca. 500 to $300 \mathrm{ka}$ ). In this basin the persistence of high edaphic humidity, even during the glacial phases, could have favoured the establishment of a refuge area for the arboreal flora and provided subsistence resources for the animal and hominin communities during the Middle Pleistocene. This could have constrained human groups to migrate into such a propitious area. Regarding the local climate evolution during the glacial episodes, the supposed displacement from these sites could be linked to the environmental dynamics solely due to the aridity increase, rather than directly to the global climate changes.

\section{Introduction}

Based on the archaeological records, the first "Out Of Africa" dispersal which led hominins to spread across Eurasia occurred sometimes around the Olduvai subchron (i.e. 1.95 to $1.78 \mathrm{Ma}$ ). Despite the consensual acceptation that the Levantine corridor was the main pathway to western Eurasia (Bar-Yosef and Belfer-Cohen, 2001; Anton and Swisher, 
2004; Schattner and Lazar, 2009; Bar-Yosef and Belmaker, 2011), the evidence of mobility towards Europe is still scattered and covers a long time period - between 1.8 and $1 \mathrm{Ma}$ (Bar-Yosef and Belfer-Cohen, 2001). Thus, a chronological and archaeological gap remains between the Caucasian site of Dmanisi, dated to the top of the Olduvai subchron (Gabunia et al., 2000; Vekua et al., 2002; Lordkipanidze et al., 2007; Messager et al., 2011a) and the earliest occupations of western Eurasia, such as Pirro Nord in Italy around 1.4 Ma (Arzarello et al., 2006; Arzarello and Peretto, 2010), Orce complex and Sima del Elefante in Spain around 1.2 Ma (Oms et al., 2000; Carbonell et al., 2008; Duval et al., 2012) or Loire Basin sites in France around 1.1 Ma (Despriée et al., 2011).

In several of such early sites, palaeobotanical and palaeontological investigation provided elements for palaeoenvironmental reconstructions. In the surroundings of sites such as Pont-de-Lavaud (France), ca. 1.2-1.1 Ma (Marquer et al., 2011) and Ca'Belvedere di Monte Poggiolo (Italy), ca. 1.2$1 \mathrm{Ma}$ (Lebreton, 2004), palynological evidence demonstrates that some of the earliest populations of Western Europe had already acquired enough plasticity to move and to occupy a large diversity of ecosystems, including Western Europe (Messager et al., 2011b), which contradicts the assumption of systematic withdrawal onto the Levantine corridor and Caucasus at each climate cycle (Leroy et al., 2011). In fact, the occupation of Pont-de-Lavaud indicates that, at around 1.1 Ma, some communities were able to settle in and to take advantage of closed environments (Marquer et al., 2011; Messager et al., 2011b), whereas in northern Italy, palaeoenvironmental studies in the site of Monte Poggiolo demonstrated that the occupation only took place in semi-open to open environments (Lebreton, 2004; Messager et al., 2011b).

Later on, the climate dynamics throughout the midPleistocene transition (MPT) strongly impacted the ecosystems, especially at the mid-latitudes (Lisiecki and Raymo, 2005; Joannin et al., 2011). Prehistoric populations located in Western Europe had to displace and settle in new territories where ecological conditions appeared more suitable for their subsistence. At the same time, hominins acquired new technical and social behaviours, as evidenced by the Mode 1 to Mode 2 transition (Grifoni and Tozzi, 2005; Peretto, 2006; Doronichev and Golovanova, 2010). In Italy both climate changes occurring since the MPT and complex physiographic settings led to the fragmentation of the environments at different scales (Russo Ermolli et al., 2010a; Manzi et al., 2011), with a fundamental dichotomy between northern and central/southern regions (Bertini, 2010). Since the Middle Pleistocene, northern Italy has been recording climatic and environmental dynamics comparable to those of continental Europe, with cold and dry glacials. On the other hand, central and southern Italy experienced a warmer climate with glacial phases mainly marked by the increase in aridity.

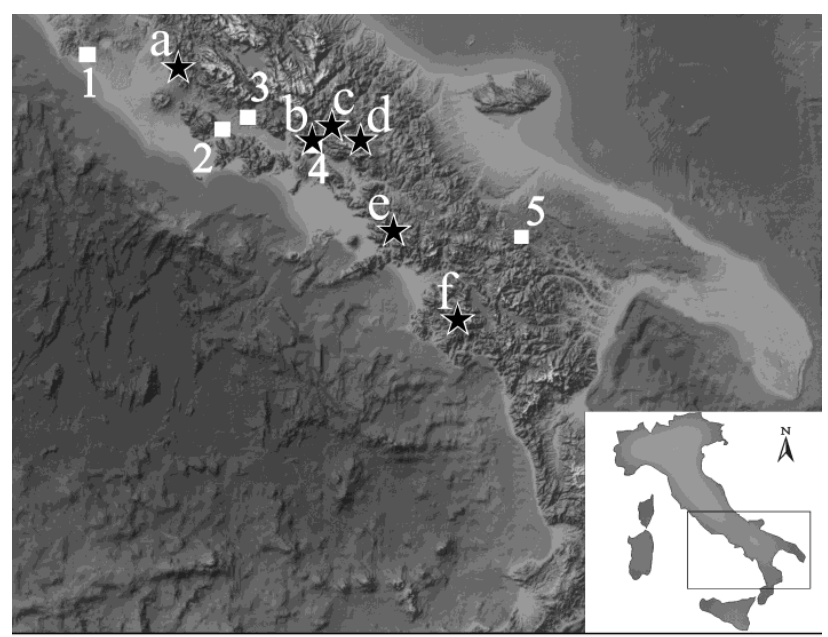

Archaeological sites Palynological sequences

1 Roma basin

2 Fontana Ranuccio

3 Ceprano

4 Isernia basin

5 Venosa basin

a Valle di Castiglione

b La Pineta

c Sessano

d Boiano

e Acerno

f Vallo di Diano

Fig. 1. Location of the compiled archaeological sites and palynological sequences.

Synchronicity of hominin occupations and palaeoenvironmental archives, locally available between the Marine Isotopic Stages (MIS) 16 and 9 in central and southern Italy, led to reinvestigation of the the regional climate and environmental dynamics, and their potential impact on the communities' displacement motivations.

\section{Regional Mode 2 archaeological settings}

Between 600 and $300 \mathrm{ka}$, a relatively high concentration of Mode 2 archaeological sites is known in central and southern Italy (Fig. 1). Despite the cultural differences among territories, archaeological evidence recorded at those sites is remarkably consistent.

\subsection{La Pineta}

La Pineta (Isernia Basin, Molise) is an important early Palaeolithic site discovered within thick fluvio-lacustrine and volcanic deposits. It consists of a large open-air succession of occupations, mainly characterized by wide bone accumulations, close to a river (Coltorti et al., 1982; Peretto, 1983). Several ${ }^{40} \mathrm{Ar} /{ }^{39} \mathrm{Ar}$ ages provided a reference age of $610 \pm 10 \mathrm{ka}$, corresponding to MIS 15 (Coltorti et al., 2005; Shao et al., 2011). The tools are considered matching with an opportunistic late Mode 1 lithic industry (Coltorti et al., 1982; Peretto, 1983; Rufo et al., 2009). La Pineta records 
abundant faunal remains attributed to the Isernia Faunal Unit (FU) of the Galerian Mammal Age (MA) (Sardella et al., 2006; Palombo and Sardella, 2007).

\subsection{Notarchirico}

The site of Notarchirico (Venosa Basin, Basilicata) is an open-air succession of occupations located on a river terrace which provided human remains and early Acheulean industries (Piperno et al., 1999). First proposed to be between 350 and $200 \mathrm{ka}$, the first stages of occupation is known placed at $640 \pm 40 \mathrm{ka}$ (MIS 16-15) using TL dating (Lefèvre et al., 2010). It is attributed to an interglacial phase, supported by microfossils and palaeontological analysis (Piperno, 1999; Lefèvre et al., 2010). The faunal assemblages recorded for the earliest stages match with the Isernia FU; however, the later mammal assemblages demonstrate the record of successive faunal phases through several interglacial phases (Cassoli et al., 1999; Sardella et al., 2006; Palombo and Sardella, 2007; Masini et al., 2013). This assumption of longlived repetitive occupations during several climatic cycles could be supported by the huge thickness of the sedimentary filling and the lithic evolution (Piperno, 1999).

\subsection{Loreto}

The site of Loreto is another succession of occupations and natural surfaces located on a terrace of the Venosa Basin (Barral and Simone, 1984). Unfortunately, it has not yet directly been dated by radioisotopic methods (Lefèvre et al., 2010). However, its lithic industry, attributed to the early Tayacian, and the palaeontological record, linked to the Fontana Ranuccio FU (Barral and Simone, 1984), as well as the analysis of the underlaying formation place Loreto later than Notarchirico, at least younger than MIS 14 (Cassoli et al., 1999; Grifoni and Tozzi, 2005; Sardella et al., 2006; Lefèvre et al., 2010; Masini et al., 2013).

\subsection{Fontana Ranuccio}

The site of Fontana Ranuccio (Latium) is an open-air site located on a terrace of the Anagni Basin, which provided a lithic industry attributed to the Acheulean culture (Ascenzi, 1984; Segre Naldini et al., 2009). The recorded faunal taxa correspond to the Fontana Ranuccio FU (Sardella et al., 2006; Palombo and Sardella, 2007; Segre Naldini et al., 2009). Formerly, K/Ar dated around $458 \mathrm{ka}$ (Segre and Ascenzi, 1984), attributing the site to the MIS 12 has not been revised by palaeomagnetism measurements (Muttoni et al., 2009). However, a new ${ }^{40} \mathrm{Ar} /{ }^{39} \mathrm{Ar}$ age obtained on single leucite crystals extracted from the same horizon previously dated by K/Ar give an age of $408 \pm 12 \mathrm{ka}$ ( $2 \mathrm{~s}$ level, relative to ACs standard at $1.193 \mathrm{Ma}$; Nomade et al., 2005), which corresponds to the MIS 11 (A. G. Segre, personal communication, 2012).

\subsection{Guado San Nicola}

The site of Guado San Nicola di Monteroduni is a recently discovered open-air occupation on a river terrace south of the Isernia Basin (C. Peretto, personal communication, 2012). It recorded a rich lithic industry characterized by a high rate of bifacial tools (around 20\%, some of important size) with a diversity of flint tools, including numerous flakes (partially linkable to opportunistic, discoid and Levallois knapping methods), several nuclei and reworking splinters. Such preliminary considerations have suggested to link the Guado San Nicola assemblage to the Acheulean. The discovered fauna seems to correspond to the Fontana Ranuccio FU. The preliminary ESR and ${ }^{40} \mathrm{Ar} /{ }^{39} \mathrm{Ar}$ results place the occupation between 380 and $350 \mathrm{ka}$, corresponding to the MIS 10 (J.J. Bahain, personal communication, 2012).

\subsection{Ceprano}

The Ceprano skull, an incomplete Homo calvarium discovered in 1994 in the Ceprano Basin (Ascenzi et al., 1996), is one of the most discussed human remains discovered in Italy, but it has not directly been linked to any archaeological site (Manzi et al., 2010). Although it has long been considered as old as the early Pleistocene, recent ${ }^{39} \mathrm{Ar} /{ }^{40} \mathrm{Ar}$ dating of an overlaying tephra layer provided a more robust age of $353 \pm 4 \mathrm{ka}$, corresponding to MIS 10 (Nomade et al., 2011). The precise attribution of this calvarium to a Homo species remains debated (Mounier et al., 2011).

\subsection{The Roma Basin}

The Roma Basin (Latium) records an important concentration of Acheulean sites dated to MIS 9, such as Castel di Guido, La Polledrara di Cecanibbio and Torre in Pietra (Radmilli and Boschian, 1996; Palombo and Sardella, 2007; Boschian and Saccà, 2010; Anzidei et al., 2012). These openair sites are located on headlands above watercourses facing the Tyrrhenian Sea, and show a remarkable coherence of faunal assemblages, corresponding to the Torre in Pietra FU of the early Aurelian MA, matching with an attribution to the MIS 9 (Sardella et al., 2006; Palombo and Sardella, 2007). Among these sites, the case of Castel di Guido is remarkable for having yielded several elephant bone bifacials and hominin remains attributed to Homo heidelbergensis (Radmilli and Boschian, 1996; Mariani-Costantini et al., 2001).

\section{Middle Pleistocene regional environmental settings}

Because of the large number of Early Palaeolithic sites and abundant Middle Pleistocene lacustrine and fluvio-palustrine sedimentary fillings of the central and southern Apennines, Quaternary basins provide synchronous regional-scale palynological and palaeontological data on environmental dynamics (Bertini, 2010; Russo Ermolli et al., 2010a,b; 
Corrado and Magri, 2011; Manzi et al., 2011). Such a concentration of pollen records, associated to the archaeological evidence (Fig. 1), improves the environmental framework in which human communities evolved.

\subsection{Vegetation records}

The new pollen analysis (Orain et al., 2012) conducted among filling record of the Boiano Basin (Fig. 2) carries out new data concerning the Middle Pleistocene vegetation evolution in southern Italy, mainly between MIS 13 and 9 (Aucelli et al., 2011). The palynological results are presented in a synthesized diagram (Fig. 3), assembling pollen taxa following their ecological requirements. The summarized description and analysis are presented in Table 1. Among the main features, the continuous record of Cyperaceae/aquatics testifies to the persistence of local edaphic humidity during the entire sequence. These singular edaphic conditions, within the overall progressive aridity increase and tree diversity decrease of the Middle Pleistocene (Bertini, 2010), led to the establishment of a refuge area, at least for the most exigent taxa, such as Carya (Orain et al., 2013). The Boiano pollen data bring out new information to understand the response of vegetation to both global climate changes and local edaphic conditions in order to appreciate the diversity of environmental conditions within the overall milder climate of central and southern Italy during the Middle Pleistocene, compared to northern parts of Italy and Europe (Bertini, 2010; Corrado and Magri, 2011; Manzi et al., 2011; Orain et al., 2012, 2013).

Figure 4 illustrates the vegetation dynamics from the main regional palynological sequences, with a lack of records for MIS 11 and 10. The selected taxa are widely considered as being the most significant palaeoecological markers. The last occurrences of Tertiary relicts were not recorded at the same time all along the peninsula, with early disappearances in the northern regions as soon as the early Pleistocene, whereas they heterogeneously persist up to Middle Pleistocene in the southern areas (Bertini, 2010; Magri and Corrado, 2010). Thus, Tsuga is lastly recorded during MIS 13, Carya during MIS 9, Pterocarya during MIS 7 and Zelkova during MIS 2 (Bertini, 2010; Corrado and Magri, 2011; Orain et al., 2013). The main trees characterizing interglacial conditions are Quercus and Carpinus for the mixed mesophytic forest, andAbies and Fagus for the montane forest. The non-arboreal pollen (NAP) regroups the herbaceous taxa, withstanding low-moisture conditions. The vegetation cycles are mainly characterized by the alternation between AP and NAP, respectively, during the interglacial and glacial episodes (Suc et al., 1995; Bertini, 2010, Corrado and Magri, 2011). However, despite the clear reduction of AP during the glacial phases, it is worth noting a relative persistence of some tree taxa such as Quercus, Carpinus and Abies. The physiography and local climate conditions of some basins led to the emergence of heterogeneous environments. The tree taxa certainly

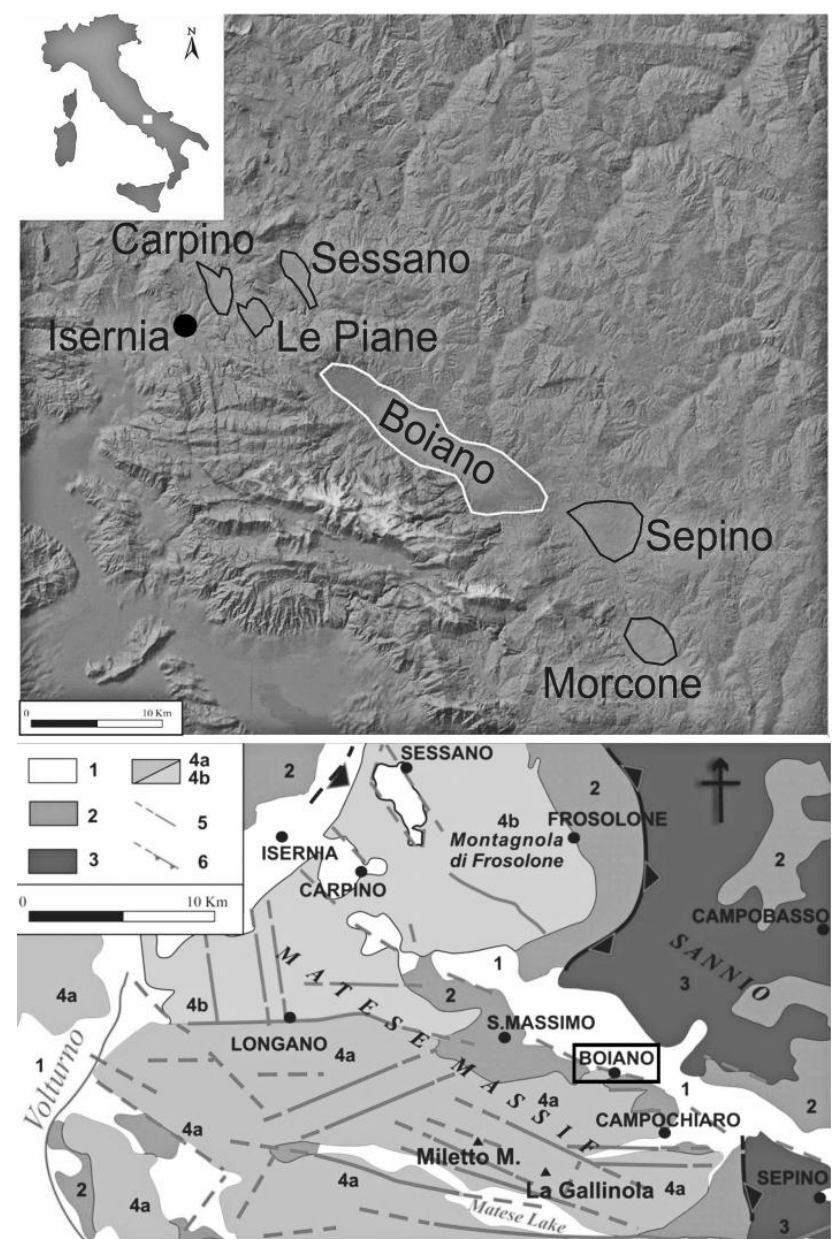

Fig. 2. Location, geological and morphotectonic contexts of the Boiano Basin $\left(49^{\circ} 29^{\prime} \mathrm{N}, 14^{\circ} 28^{\prime} \mathrm{E}\right.$; ca. $500 \mathrm{~m}$ a.s.l.) and of the main close sedimentary basins of the Molise region (from Aucelli et al., 2011). 1: fluviopalustrine deposits (Quaternary); 2: siliciclastic deposits (Miocene); 3: clays, marls and limestones of Sannio (Upper Cretaceous to Miocene); 4: limestones, dolomites, marls of carbonate platform (a) and carbonate slope deposits (b) (Triassic to Miocene); 5: main thrusts; 6: main extensional faults.

benefited from edaphic and/or climatic humidity persistence during the glacials within step-sided plains of the Apennines, and then redeveloped during the interglacial milder conditions (Bertini, 2010; Corrado and Magri, 2011; Manzi et al., 2011; Orain et al., 2012, 2013). Some of such protected basins of the central and southern Apennines could then have been propitious for forests withdrawal, increasing the capacity of resilience of arboreal taxa during the most arid periods (Bertini, 2010; Corrado and Magri, 2011; Manzi et al., 2011; Orain et al., 2012, 2013). 
Table 1. Isotopic correlations and summary description of the palynological sequence of the Boiano Basin, including main biome deduced from pollen assemblages (from Orain et al., 2012).

\begin{tabular}{|c|c|c|c|}
\hline MIS correlation & Pollen zone & Pollen signature & Main biome \\
\hline MIS 8 to MIS 2 & LPZ 4 & $\begin{array}{l}\text { Heterogenous pollen and sedimentary records } \\
\text { sedimentary fillings of the basin?* }\end{array}$ & - \\
\hline \multirow[t]{2}{*}{ MIS 9} & LPZ 3b & $\begin{array}{l}\text { Abies dominant with Picea, } \\
\text { mixed deciduous forest decreasing and } \\
\text { impoverishing* }\end{array}$ & Coniferous forest \\
\hline & LPZ 3a & $\begin{array}{l}\text { Quercus/Fagus (dominant) decreasing, } \\
\text { progressive augmentation of deciduous trees } \\
\text { diversity, Carya present ( } \max \approx 5 \% \text { of } \mathrm{AP}), \\
\text { Coniferous (Abies, Picea, Cedrus) increasing* }\end{array}$ & Mesophilous forest \\
\hline MIS 12 to MIS 10 & LPZ 2 & $\begin{array}{l}\text { Herb dominance with steppic association, } \\
\text { local evidence of reworked material, } \\
\text { occasional occurrences of several trees* }\end{array}$ & Steppe \\
\hline MIS 13 & LPZ 1 & $\begin{array}{l}\text { Abies and Picea increasing ( } 10 \text { to } 30 \% \text { ), } \\
\text { Pinus progressing (concentration), } \\
\text { Fagus decreasing ( } 10 \text { to } 0 \% \text { ), } \\
\text { mixed deciduous forest (with Carya) around } 10 \% \text {, } \\
\text { hygrophylous locally decreasing* }\end{array}$ & Coniferous forest \\
\hline
\end{tabular}

* Continuous occurrences of local edaphic humidity (attested by hygrophylous plants).
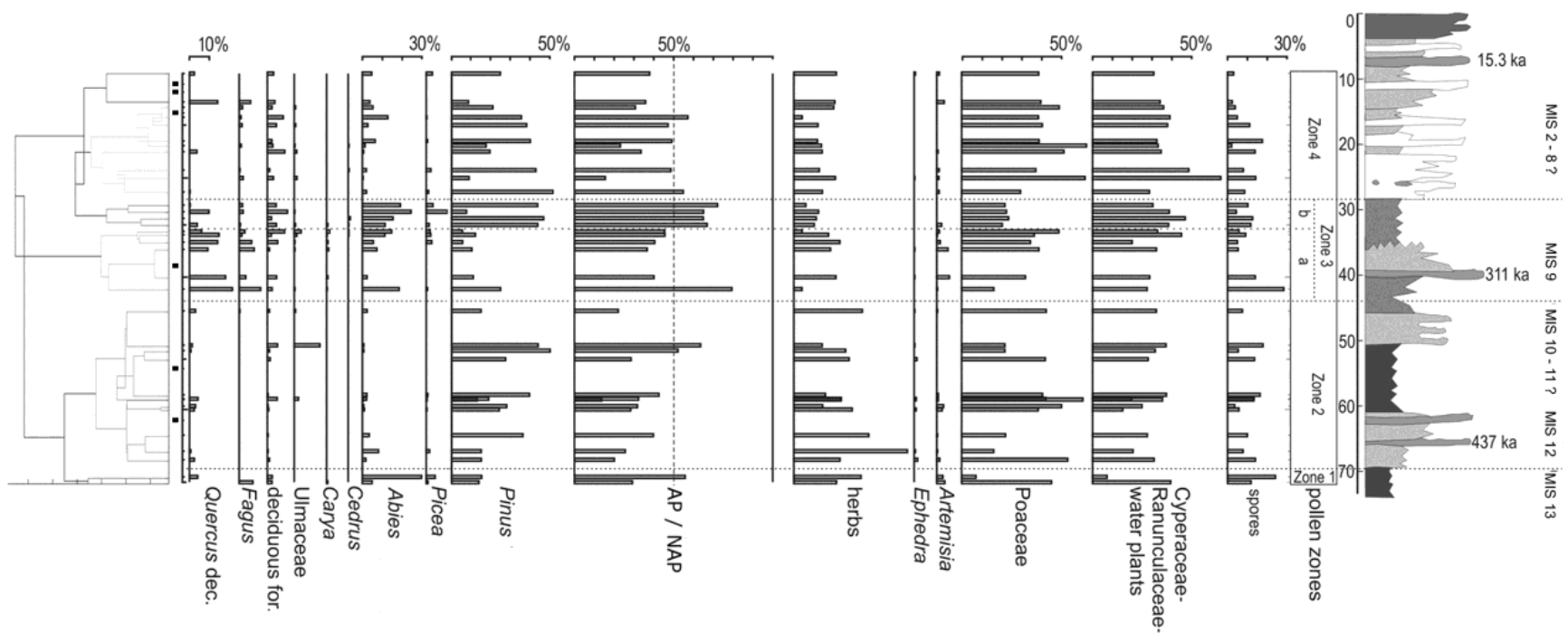

Fig. 3. Synthesized pollen diagram of core S6 from Boiano, with position of barren samples . Taxa are grouped according to their ecological significance (after Orain et al., 2012, 2013).

\subsection{Faunal records}

The numerous faunal assemblages from archaeological sites provide an important background for inquiring the subsistence behaviour of hominin communities, in relation to the exploited environments (Radmilli and Boschian, 1996; Cassoli et al., 1999; Raia et al., 2005; Sardella et al., 2006; Palombo and Sardella, 2007; Thun Hohenstein et al., 2009; Boschian and Saccà, 2010; Anzidei et al., 2012; Magri and
Palombo, 2013). The main predated taxa identified in each site, and therefore the types of environments the hominin communities exploited, are summarized in Table 2.

The faunal records of the studied period partially cover two successive MA, from the Middle Galerian (Isernia FU) to the early Aurelian (Torre in Pietra FU). Therefore, human communities had to adapt their activities to the evolution of the ecosystems, especially during these faunal turnovers. Subsistence behaviour analysis from the earliest sites ( $\mathrm{La}$ 


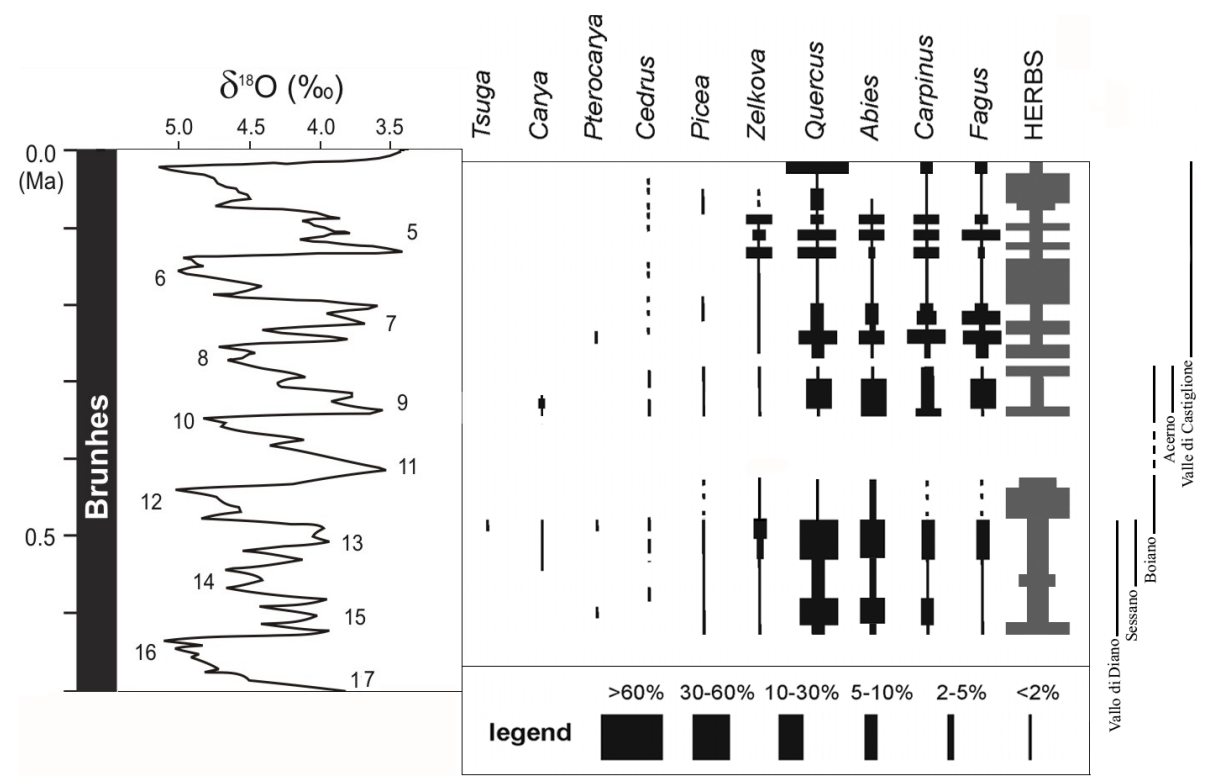

Fig. 4. Synthesized diagram of the local palynological studies, presenting the dynamics of the main taxa for the studied period, compiled from Vallo di Diano (Russo Ermolli, 1994), Sessano (Russo Ermolli et al., 2010b), Boiano (Orain et al., 2012), Acerno (Munno et al., 2001) and Valle di Castiglione (Follieri et al., 1988) sequences (modified from Manzi et al., 2011).

Pineta and Notarchirico) highlighted that the local populations mainly selected the faunal species offering the most economically profitable volume of muscular mass (Cassoli et al., 1999; Thun Hohenstein et al., 2009). These studies have also demonstrated that hominins had already acquired active predation behaviours, including specimen selections, with only occasional scavenging. It is then possible to deduce the hominin main predation strategies and to identify the environments they preferably exploited, even starting from the earliest sites. Regarding the environments associated to the predation activities, mixed orientations towards closed to semi-open ecosystems appear across the region (Table 2).

At La Pineta, the hunting and butchery testimonies clearly indicate that Bison schoetensacki constituted the main target (Thun Hohenstein et al., 2009). However, records of several other taxa from a large panel of ecosystems confirm that hunting was also conducted in different types of environments. This diversity directly attests to the benefit of the environmental diversity (Thun Hohenstein et al., 2004, 2009), despite a non-anthropic accumulation effect having to be considered.

At Notarchirico, the faunal records across the different layers show that the local populations had repetitively exploited almost indifferently closed and semi-open environments (Cassoli et al., 1999; Sardella et al., 2006). Later, at Loreto, the faunal record presents the same type of repetitive exploitation of various environments, despite these sites probably being occupied and exploited by two different populations, in regards to their lithic cultures (Barral and Simone, 1984; Cassoli et al., 1999; Grifoni and Tozzi, 2005).
The faunal remains discovered in the site of Guado San Nicola di Monteroduni, even if preliminary, also attest to a predation oriented towards a diversity of environments, although the semi-open to open ones seem dominating. This singular situation could be linked to the opening of the environments in response to the glacial conditions. However, despite the probable reduction of their habitats, mammals from closed environments remain predated.

After the turnover of the late Galerian-early Aurelian MA, the faunal assemblages recorded in the Roma Basin sites are characterized by a mixed exploitation of semi-open and closed environments, (Radmilli and Boschian, 1996; Sardella et al., 2006; Palombo and Sardella, 2007; Boschian and Saccà, 2010; Anzidei et al., 2012).

Across the entire studied period, hominins globally tended to benefit and to adapt to the diversity of available ecosystems, regardless of their cultural tradition. The flexibility and plasticity of these hominin communities certainly entertained their capacity to settle and exploit a large range of environmental conditions (Messager et al., 2011b), and to develop predation strategies taking the benefits of this diversity (Sardella et al., 2006; Palombo and Sardella, 2007; Thun Hohenstein et al., 2009; Manzi et al., 2011).

\section{Environmental dynamics and human mobility}

As previously mentioned, the early Palaeolithic archaeological sites discovered up to now in central and southern Italy and dated to the Middle Pleistocene show a global coherence of nature and activities despite the different chronological 
Table 2. Summary of the main taxa recorded on each studied site and the associated exploited environments.

\begin{tabular}{|c|c|c|c|}
\hline $\begin{array}{l}\text { Site } \\
\text { (Biozone attribution) }\end{array}$ & Recorded taxa & $\begin{array}{l}\text { Main exploited } \\
\text { environments }\end{array}$ & References \\
\hline $\begin{array}{l}\text { La Pineta } \\
\text { (Isernia FU, MIS 15) }\end{array}$ & $\begin{array}{l}\text { Bison schoetensacki, } \\
\text { Elephas (Palaeoloxodon) antiquus, } \\
\text { Stephanorhinus hundsheimensis, } \\
\text { Megaloceros solihacus, } \\
\text { Cervus elaphus, } \\
\text { Dama clatoniana }\end{array}$ & $\begin{array}{l}\text { Associations of closed } \\
\text { forested environments } \\
\text { and grasslands } \\
\text { to semi-open woodlands }\end{array}$ & Thun Hohenstein et al. $(2004,2009)$ \\
\hline $\begin{array}{l}\text { Notarchirico } \\
\text { (Isernia FU, MIS 15+) }\end{array}$ & $\begin{array}{l}\text { Elephas (Palaeoloxodon) antiquus, } \\
\text { Dama clatoniana, } \\
\text { Cervus elaphus, } \\
\text { Praemegaceros sp., } \\
\text { Axis sp., } \\
\text { Bos primigenius, } \\
\text { Bison schoetensacki }\end{array}$ & $\begin{array}{l}\text { Associations of closed } \\
\text { forested environments } \\
\text { and grasslands } \\
\text { to semi-open woodlands }\end{array}$ & $\begin{array}{l}\text { Cassoli et al. (1999); } \\
\text { Sardella et al. (2006) }\end{array}$ \\
\hline $\begin{array}{l}\text { Loreto } \\
\text { (Isernia FU, MIS 13) }\end{array}$ & $\begin{array}{l}\text { Bison schoetensacki, } \\
\text { Elephas (Palaeoloxodon) antiquus, } \\
\text { Stephanorhinus hundsheimensis }\end{array}$ & $\begin{array}{l}\text { Associations of closed } \\
\text { forests and grasslands } \\
\text { to semi-open woodlands }\end{array}$ & Sardella et al. (2006) \\
\hline $\begin{array}{l}\text { Fontana Ran. } \\
\text { (Fontana Ran. FU, MIS 11) }\end{array}$ & $\begin{array}{l}\text { Elephas (Palaeoloxodon) antiquus, } \\
\text { Stephanorhinus hemitoechus, } \\
\text { Equus mosbachensis, } \\
\text { Sus scrofa, } \\
\text { Megaloceros solihacus, } \\
\text { Cervus elaphus, } \\
\text { Dama clatoniana, } \\
\text { Megaloceros verticornis, } \\
\text { Bos primigenius, } \\
\text { Bison schoetensacki, } \\
\text { Hippopotamus amphibius }\end{array}$ & $\begin{array}{l}\text { Associations of closed } \\
\text { forested environments } \\
\text { and grasslands } \\
\text { to semi-open woodlands }\end{array}$ & $\begin{array}{l}\text { Ascenzi (1984) } \\
\text { Segre Naldini et al. (2009) }\end{array}$ \\
\hline $\begin{array}{l}\text { Guado San Nicola } \\
\text { (Fontana Ran. FU, MIS 10) }\end{array}$ & $\begin{array}{l}\text { Elephas (Palaeoloxodon) antiquus, } \\
\text { Equus sp., } \\
\text { Bison schoetensacki, } \\
\text { Megaloceros sp., } \\
\text { Cervus elaphus }\end{array}$ & $\begin{array}{l}\text { Associations of } \\
\text { closed grasslands } \\
\text { to open woodlands, } \\
\text { punctually local forests }\end{array}$ & Unpublished to date \\
\hline $\begin{array}{l}\text { Roma Basin sites } \\
\text { (Torre in Pietra FU, MIS 9) }\end{array}$ & $\begin{array}{l}\text { Elephas (Palaeoloxodon) antiquus, } \\
\text { Bos primigenius, } \\
\text { Equus ferus, } \\
\text { Cervus elaphus }\end{array}$ & $\begin{array}{l}\text { Associations of closed } \\
\text { forested environments } \\
\text { and grasslands } \\
\text { to open woodlands }\end{array}$ & $\begin{array}{l}\text { Radmilli and Boschian (1996); } \\
\text { Sardella et al. (2006); } \\
\text { Palombo and Sardella (2007); } \\
\text { Boschian and Saccà (2010); } \\
\text { Anzidei et al. (2012) }\end{array}$ \\
\hline
\end{tabular}

and climate contexts. Another important feature in all the studied sites is the clear exploitation of the available environmental diversity for subsistence. However, the elongation and intensification of the glacial phases since the Middle Pleistocene led to the reduction of closed environments in response to the long term aridity increase, especially in open valleys. Consequently, the lack of archaeological records during the glacial episodes could reflect the abandonment of these sites, owing to environmental changes. In fact, as a part of the ecological communities, hominins probably sustained themselves in a large territory following flora and fauna displacements as the ecosystems fragmented in a mosaic of micro-environments during the glacial phases.

\subsection{Evidence for glacial occupations}

Since the two last decades, new evidence of local persistence of human communities has been highlighted. The Ceprano skull, as well as the footprint from the BLT on the slope of the Roccamonfina volcano, constitute well-dated records of human presence during a glacial phase in central Italy even if they cannot be directly linked to any precise hominin settlement (Ascenzi et al., 1996; Scaillet et al., 2008; Manzi 
et al., 2010; Nomade et al., 2011). Recently, lithic and faunal remains discovered at Guado San Nicola (i.e. MIS 10) attest to hominin occupation during a glacial phase. The site was located on the shores of a river, and the local humidity, highlighted by the sedimentary filling, could have favoured the persistence of forested communities and consequent diversity of exploitable environments. Thus, to date, no other site apart from Guado San Nicola has clearly presented evidence of long-lived occupation through several climate phases, although potential taphonomical processes could have occurred (Coltordi et al., 1982; Radmilli and Boschian, 1996; Piperno, 1999; Palombo and Sardella, 2007; Rufo et al., 2009; Segre Naldini et al., 2009; Boschian and Saccà, 2010; Manzi et al., 2011; Anzidei et al., 2012). However, the Venosa Basin sites witnessed several phases of occupation. Indeed, Notarchirico and Loreto recorded multiple layers with heterogeneous palaeontological assemblages that could reflect succession of occupations at different times, although no glacial evidence has been recorded within the archaeological layers (Cassoli et al., 1999; Piperno, 1999; Palombo and Sardella, 2007, Masini et al., 2013). Systematic dating and measurements of these archaeological layers have to be undertaken in order to highlight eventual long-lived or repetitive occupations across glacial and interglacial phases in those sites.

\subsection{Long-distance mobility}

Potential long-distance movements do not seem to be an efficient model for hominin communities settled in central and southern Italy. In fact, long-distance mobility was limited to the east and the west by the Adriatic and Tyrrhenian seas, and then would have been directed northward. However, the climate of northern Italy during the Middle Pleistocene was significantly colder and drier with respect to the southern and central regions due to its latitudinal position and proximity to the Alps' ice sheet (Bertini, 2010; Palombo and Sardella, 2007; Corrado and Magri, 2011; Manzi et al., 2011), and this would have constrained human groups to fundamentally modify their behaviour in order to face radically different environments. Successive human adaptations to environmental changes after each phase should be detected within the cultural evolution, but the local evidence has not been recorded to date (Grifoni and Tozzi, 2005; Peretto, 2006; Doronichev and Golovanova, 2010). An opposite hypothesis could be that the cultural evolution was linked to southward movements of northern populations towards central and southern Italy (Grifoni and Tozzi, 2005; Peretto, 2006; Doronichev and Golovanova, 2010; Manzi et al., 2011). Thus, the milder climate conditions recorded in central and southern Italian peninsula, compared to northern parts of Europe, may have constituted attractive areas for allochtonous populations, leading to cultural developments and demographic expansions.

\subsection{Regional mobility}

Considering the relative continuity of occupations in central and southern Italy between 600 and $300 \mathrm{ka}$, hominin mobility at a regional scale has to be considered. This assumption is supported by the repetitive occupations of the Venosa Basin (Cassoli et al., 1999; Piperno, 1999; Palombo and Sardella, 2007, Masini et al., 2013). During the glacial phases, the aridity increase constrained vegetation to limited favourable environments (Bertini, 2010; Corrado and Magri, 2011; Manzi et al., 2011; Orain et al., 2012, 2013). At least part of the mammal communities had also to migrate, following their main ecosystems (Palombo, 2010). Some of the most predated taxa indicates that the site abandonments could be a consequence of hominin mobility in their search for subsistence, i.e. following animal communities (including forest dwellers). (Palombo, 2010). The diversity of local conditions certainly led to the formation of local ecological refuges in some of the protected Apennines basins (Bertini, 2010; Orain et al., 2013). Potential reinstallations of hominins along the coastal plains have also to be considered. However, such sites are not recorded, probably submerged due to sea level rise (Marturano et al., 2011). It could then be assumed that these local protected environments contained most of the forest and faunal communities. Furthermore, the Italian peninsula shows a global trend of reduction of forest mammals related to open environment expansion since the Villafranchian MA in the Italian peninsula (Palombo, 2010). Such assumption is consistent with the global environmental dynamics (Bertini, 2010; Manzi et al., 2011; Magri and Palombo, 2013). Nevertheless, in all the studied sites, forest mammal taxa are sub-dominant to dominant, mainly with Dama and Cervus (locally with Axis), and also with forested grassland taxa such as Bison schoetensacki, Bos primigenius and Megaloceros (Radmilli and Boschian, 1996; Cassoli et al., 1999; Thun Hohenstein et al., 2004; Sardella et al., 2006; Palombo and Sardella, 2007; Thun Hohenstein et al., 2009; Boschian and Saccà, 2010; Palombo, 2010; Anzidei et al., 2012. Magri and Palombo, 2013). Furthermore, Bovidea are, after Elephantidea, the most frequently used animal material in the Acheulean bone industry of central Italy (Peretto, 2006; Grifoni and Tozzi, 2005; Palombo and Sardella, 2007; Boschian and Saccà, 2010; Doronichev and Golovanova, 2010; Anzidei et al., 2012). The exploitation of such mixed fauna appears to be an early active choice, related to the benefit (benefice is church related) of their exploitation (Palombo and Sardella, 2007; Thun Hohenstein et al., 2009; Magri and Palombo, 2013). Such subsistence behaviours applied to large territories could have triggered hominins to exploit various ecosystems or to directly settle within refuge areas propitious to vegetation and faunal diversity.

However, target changes in response to the progressive opening of ecosystems could not be excluded, considering the increasing place and domination of the open environment dwellers (Radmilli and Boschian, 1996; Cassoli et al., 1999; 
Sardella et al., 2006; Thun Hohenstein et al., 2009; Boschian and Saccà, 2010; Palombo, 2010; Anzidei et al., 2012). This long-term open-environment persistence could have progressively triggered a reorientation or concentration of human predation towards open-environment dwellers (Palombo, 2010). Human response could then have consisted in flexibility and adaptability of environmental exploitation, at local or regional scales.

\section{Conclusions}

Middle Pleistocene environmental data from central and southern Italy constitute a strong ecological framework to study hominin evolution and mobility. At local and regional scales, the palaeontological and palynological studies provide numerous contextual data to reconstruct the complexity and diversity of the environments in which the hominins settled. Evidence for heterogeneous environmental conditions have already been emphasized by several studies, and are supported by the Boiano pollen sequence, which highlighted singular refuge conditions for the forest communities. Within these ecosystems, analyses of subsistence behaviours illustrate part of the hominin strategies during the Middle Pleistocene. The diversity of exploited ecosystems recorded during each interglacial episode reflects key issues regarding potential hominin mobility triggered by climate and environmental changes during the preceding glacial phase. However, the current lack of data for human activity during the glacial episodes calls for a new perspective drawn from both environmental and prehistoric studies. These interruptions in the settlement record could have resulted from the abandonment of these sites by their prehistoric occupants who would have followed the faunal communities on which they subsisted. Considering the mild and temperate conditions in central and southern Italy, both local faunal and human communities could also have adapted locally to the opening up of their environments, or, regionally, could have moved to benefit from the ambient diversity.

The archaeological material and sedimentary sequences already demonstrated that central and southern Italian climate and environment during the Middle Pleistocene certainly attracted northern European communities, contributing to the cultural and demographic developments. Further investigations will provide complementary data to deliver key issues on this crucial topic.

Acknowledgements. The authors thank F. Viehberg and the co-conveners for granting them the opportunity to present their research at the EGU 2012 symposium "Walking on Sunshine". They also thank V. Amato and P. Aucelli for their close collaboration on the Boiano sequence study, P. Auguste for his useful clarifications concerning mammal palaeoecology, and A. G. Segre for his useful data on Fontana Ranuccio. This work has been funded by the project "Chronologie des occupations acheuléenes en Europe occidentale" within the MNHN Transversal Action "Relation Sociétiés-Nature dans le long terme", and with the financial support of the "Association des Palynologues de Langue Française". We also express our gratitude to the C. Hunt, A. Bruch and an anonymous referee, and to D. Magri and G. Scardia for their useful comments and the improvement of this manuscript.

Edited by: F. Viehberg

\section{References}

Anton, S. C. and Swisher, C. C.: Early dispersals of Homo from Africa, Annu. Rev. Anthropol., 33, 271-296, 2004.

Anzidei, A. P., Bulgarelli, G. M., Catalano, P., Cerilli, E., Gallotti, R., Lemorini, C., Milli, S., Palombo, M. R., Pantano, W., and Santucci, E.: Ongoing research at the late Middle Pleistocene site of La Polledrara di Cecanibbio (central Italy), with emphasis on human-elephant relationships, Quatern. Int., 255, 171-187, 2012.

Arzarello, M. and Peretto, C.: Out of Africa: The first evidence of Italian peninsula occupation, Quatern. Int., 223-224, 65-70, 2010.

Arzarello, M., Marcolini, F., Pavia, G., Pavia, M., Petronio, C., Petrucci, M., Rook, L., and Sardella, R.: Evidence of earliest human occurrence in Europe: the site of Pirro nord (Southern Italy), Naturwissenschaften, 94, 107-112, 2006.

Ascenzi, A.: Rinvenimento di dente umano nell'acheuleano inferiore ad Anagni-Fontana Ranuccio Frosinone, Atti della XXIV riunione scientifica dell' Istituto Italiano di Preistoria e Protostoria, 24, 113-114, 1984.

Ascenzi, A., Biddittu, I., Cassoli, P. F., Segre, A. G., and Segre Naldini, E.: A calvarium of late Homo erectus from Ceprano, Italy, J. Hum. Evol., 31, 409-423, 1996.

Aucelli, P., Amato, V., Cesarano, M., Pappone, G., Rosskopf, C. M., Russo Ermolli, E., and Scarciglia, F.: New morphostratigraphic and chronological constraints for the Quaternary palaeosurfaces of the Molise Apennines (southern Italy), Geol. Carpath., 62, 1726, 2011.

Bar-Yosef, O., and Belfer-Cohen A.: From Africa to Eurasia - early dispersals, Quatern. Int., 7, 19-28, 2001.

Bar-Yosef, O. and Belmaker, M.: Early and Middle Pleistocene Faunal and hominins dispersals through Southwestern Asia, Quaternary Sci. Rev., 30, 1318-1337, 2011.

Barral, L. and Simone, S., in: Venosa - Loreto, Basilicata, in I primi abitanti d'Europa, Catalogo della Mostra, De Luca Editore, Roma, 105-112, 1984.

Bertini, A.: Pliocene to Pleistocene palynoflora and vegetation in Italy: State of the art, Quatern. Int., 225, 5-24, 2010.

Boschian, G. and Saccà, D.: Ambiguities in human and elephant interactions? Stories of bones, sand and water from Castel di Guido (Italy), Quatern. Int., 214, 3-16, 2010.

Carbonell, E., Bermúdez de Castro, J. M., Parés, J. M., PérezGonzález, A., Cuenca-Bescós, G., Olle, A., Mosquera, M., Huguet, R., van der Made, J., Rosas, A., Sala, R., Vallverdú, J., Garcia, N., Granger, D. E., Martinón-Torres, M., Rodríguez, X. P., Stock, G. M., Vergès, J. M., Allué, E., Burjachs, F., Cáceres, I., Canals, A., Benito, A., Díez, C., Lozano, M., Mateos, A., Navazo, M., Rodríguez, J., Rosell, J., and Arsuaga, J. L.: The first hominin of Europe, Nature, 452, 465-470, 2008. 
Cassoli, P. F., Di Stefano, G., Tagliacozzo, A., and Piperno, M. (Eds.): Notarchirico, Un sito del Pleistocene medio iniziale nel Bacino di Venosa, Museo Pigorini, Roma, Edizioni Osanna, Venosa, 1999.

Coltorti, M., Cremaschi, M., Delitala, M. C., Esu, D., Fornaseri, M., McPherron, A., Nicoletti, M., Van Otterloo, R., Peretto, C., Sala, B., Schmidt, V., and Sevink, J.: Reversed magnetic polarity at an early Lower Palaeolithic site in Central Italy, Nature, 300, 173-176, 1982.

Coltorti, M., Feraud, G., Marzoli, A., Peretto, C., Ton-That, T., Voinchet, P., Bahain, J.-J., Minelli, A., and Thun Hohenstein, U.: New ${ }^{40} \mathrm{Ar} /{ }^{39} \mathrm{Ar}$, stratigraphic and palaeoclimatic data on the Isernia La Pineta Lower Palaeolithic site, Molise, Italy, Quatern. Int., 131, 11-22, 2005.

Corrado, P. and Magri, D.: A late Early Pleistocene pollen record from Fontana Ranuccio (central Italy), J. Quaternary Sci., 26, 335-344, 2011.

Despriée, J., Voinchet, P., Tissoux, H., Bahain, J.-J., Falguères, C., Courcimault, G., Dépont, J., Moncel, M.-H., Robin, S., Arzarello, M., Sala, R., Marquer, L., Messager, E., Puaud, S., and Abdessadok, S.: Lower and Middle Pleistocene human settlements recorded in fluvial deposits of the middle Loire River Basin, Centre Region, France, Quaternary Sci. Rev., 30, 1474 1485, 2011.

Doronichev, V. and Golovanova, L.: Beyond the Acheulean: A view on the Lower Paleolithic occupation of Western Eurasia, Quatern. Int., 223-224, 327-344, 2010.

Duval, M., Falguères, C., Bahain, J.-J., Grün, R., Shao, Q., Aubert, M., Dolo, J.-M., Agustí, J., Martínez-Navarro, B., Palmqvist, P., and Toro-Moyano, I.: On the limits of using combined Useries/ESR method to date fossil teeth from two Early Pleistocene archaeological sites of the Orce area (Guadix-Baza basin, Spain), Quaternary Res., 77, 482-491, 2012.

Follieri, M., Magri, D., and Sadori, L.: 250,000-year pollen record from Valle di Castiglione (Roma), Pollen et Spores, 30, 329-356, 1988.

Gabunia, L., Vekua, A., Lordkipanidze, D., Swisher III, C. C., Ferring, R., Justus, A., Nioradze, M., Tvalcrelidze, M., Anton, S. C., Bosinski, G., Jöris, O., Lumley de, M. A., Majsuradze, G., and Mouskhelishvili, A.: Earliest Pleistocene hominid cranial remains from Dmanisi, Republic of Georgia: taxonomy, geological setting, and age, Science, 288, 1019-1025, 2000.

Grifoni, R. and Tozzi, C.: L'émergence des identités culturelles au Paléolithique inférieur: le cas de l'Italie, C. R. Palevol., 5, 137148,2005

Joannin, S., Bassinot, F., Combourieu Nebout, N., Peyron, O., and Beaudoin, C.: Vegetation response to obliquity and precession forcing during the Mid-Pleistocene Transition in Western Mediterranean region (ODP site 976), Quaternary Sci. Rev., 30, 280-297, 2011.

Lebreton, V.: Paysages et climats contemporains des premiers hominidés en Italie, BAR Int. Ser. 1204, Oxford, UK, 2004.

Lefèvre, D., Raynal, J.-P., Vernet, G., Kieffer, G., and Piperno, M.: Tephro-stratigraphy and the age of ancient Southern Italian Acheulean settlements: The sites of Loreto and Notarchirico (Venosa, Basilicata, Italy), Quatern. Int., 223-224, 360-368, 2010.

Leroy, S. A. G., Arpe, K., and Mikolajewicz, U.: Vegetation context and climatic limits of the Early Pleistocene hominin dispersal in
Europe, Quaternary Sci. Rev., 30, 1448-1463, 2011.

Lisiecki, L. E. and Raymo, M. E.: Plio-Pleistocene climate evolution: trends and transitions in glacial cycle dynamics, Quaternary Sci. Rev., 26, 56-69, 2005.

Lordkipanidze, D., Jashashvili, T., Vekua, A., Ponce de León, M. S., Zollikofer, C. E., Rightmire, G. P., Pontzer, H., Ferring, R., Oms, O., Tappen, M., Bukhsianidze, M., Agustí, J., Kahlke, R., Kiladze, G., Martínez-Navarro, B., Mouskhelishvili, A., Nioradze, M., and Rook, L.: Postcranial evidence from early Homo from Dmanisi, Georgia, Nature, 449, 305-310, 2007.

Magri, D. and Palombo, M. R.: Early to Middle Pleistocene dynamics of plant and mammal communities in South West Europe, Quatern. Int., 288, 63-72, doi:10.1016/j.quaint.2012.02.028, 2013.

Manzi, G., Magri, D., Milli, S., Palombo, M. R., Margari, V., Celiberti, V., Barbieri, M., Barbieri, M., Melis, R. T., Rubini, M., Ruffo, M., Saracino, B., Tzedakis, P. C., Zarattini, A., and Biddittu, I.: The new chronology of the Ceprano calvarium (Italy), J. Hum. Evol., 59, 580-585, 2010.

Manzi, G., Magri, D., and Palombo, M. R.: Early-Middle Pleistocene environmental changes and human evolution in the Italian peninsula, Quaternary Sci. Rev., 30, 1420-1438, 2011.

Mariani-Costantini, R., Ottini, L., Caramiello, S., Palmirotta, R., Mallegni, F., Rossi, A., Frati, L., and Capasso, L.: Taphonomy of the fossil hominid bones from the Acheulean site of Castel di Guido near Rome, Italy, J. Hum. Evol., 41, 211-225, 2001.

Marquer, L., Messager, E., Renault-Miskovsky, J., Despriée, J., Gageonnet, R., Voinchet, P., Bahain, J.-J., and Falguères, C.: Paléovégétation du site à hominidés de Pont-de-Lavaud, Pléistocène inférieur, Région Centre, France, Quaternaire, 22, 187-200, 2011.

Marturano, A., Aiello, G., and Barra, D.: Evidence for Late Pleistocene uplift at the Somma-Vesuvius apron near Pompeii, J. Volcanol. Geoth. Res., 202, 211-227, 2011.

Masini, F., Palombo, M. R., and Rozzi, R.: A reappraisal of the Early to Middle Pleistocene Italian Bovidae, Quatern. Int., 288, 45-62, doi:10.1016/j.quaint.2012.03.026, 2013.

Messager, E., Nomade, S., Voinchet, P., Ferring, R., Mgeladze, A., Guillou, H., and Lordkipanidze, D.: ${ }^{40} \mathrm{Ar} /{ }^{39} \mathrm{Ar}$ dating and phytolith analysis of the Early Pleistocene sequence of KvemoOrozmani (Republic of Georgia): chronological and palaeoecological implications for the hominin site of Dmanisi, Quaternary Sci. Rev., 30, 3099-3108, 2011a.

Messager, E., Lebreton, V., Marquer, L., Russo-Ermolli, E., Orain, R., Renault-Miskovsky, J., Lordkipanidze, D., Despriée, J., Peretto, C., and Arzarello, M.: Palaeoenvironments of early hominins in temperate and Mediterranean Eurasia: new palaeobotanical data from Palaeolithic key-sites and synchronous natural sequences, Quaternary Sci. Rev., 30, 1439-1447, 2011 b.

Mounier, A., Condemi, S., and Manzi, G.: The Stem Species of Our Species: A Place for the Archaic Human Cranium from Ceprano, Italy, PLoS ONE, 6, e18821, doi:10.1371/journal.pone.0018821, 2011.

Munno, R., Petrosino, P., Romano, P., Russo Ermolli, E., and Juvigné, E.: A late Middle Pleistocene climatic cycle in southern Italy inferred from pollen analysis and tephrostratigraphy of the Acerno lacustrine succession, Geogr. Phys. Quatern., 55, 87-99, 2001. 
Muttoni, G., Scardia, G., Kent, D. V., Swisher, C. C., and Manzi, G.: Pleistocene magnetochronology of early hominin sites at Ceprano and Fontana Ranuccio, Italy, Earth Planet. Sc. Lett., 286, 255-268, 2009.

Nomade, S., Renne, P. R., Vogel, N., Deino, A. L., Sharp, W. D., Becker, T. A., Jaouni, A. R., and Mundil, R.: Alder Creek sanidine (ACs-2): A Quaternary ${ }^{40} \mathrm{Ar} /{ }^{39} \mathrm{Ar}$ dating standard tied to the Cobb Mountain geomagnetic event, Chem. Geol., 218, 315-338, 2005.

Nomade, S., Muttoni, G., Guillou, H., Robin, E., and Scardia, G.: First ${ }^{40} \mathrm{Ar} /{ }^{39} \mathrm{Ar}$ age of the Ceprano man (central Italy), Quat. Geochronol., 6, 453-457, 2011.

Oms, O., Parés, J. M., Martinez-Navarro, B., Agusti, J., Toro, I., Martinez-Fernandez, G., and Turq, A.: Early human occupation of Western Europe: paleomagnetic dates for two paleolithic sites in Spain, P. Natl. Acad. Sci. USA, 97, 10666-10670, 2000.

Orain, R., Lebreton, V., Russo Ermolli, E., Aucelli, P., and Amato, V.: Végétation et climat au Pléistocène Moyen en Italie Méridionale (Bassin de Boiano, Molise), Quaternaire, 23, 37-48, 2012.

Orain, R., Lebreton, V., Russo Ermolli, E., Combourieu-Nebout, N., Sémah, A.-M.: Carya as marker for tree refuges in southern Italy (Boiano basin) at the Middle Pleistocene, Palaeogeogr. Palaeocl., 369, 295-302, 2013.

Palombo, M. R.: A scenario of human dispersal in the northwestern Mediterranean throughout the Early to Middle Pleistocene, Quatern. Int., 223-224, 179-194, 2010.

Palombo, M. R. and Sardella, R.: Biochronology and biochron boundaries: A real dilemma or a false problem? An example based on the Pleistocene large mammalian faunas from Italy, Quatern. Int., 160, 30-42, 2007.

Peretto, C. (Ed.): Isernia La Pineta: un accampamento più antico di 700.000 anni, Calderini Editore, Bologna, 41-47, 1983.

Peretto, C.: The first peopling of Southern Europe: the Italian case, C. R. Palevol., 5, 283-290, 2006.

Piperno, M. (Ed.): Notarchirico, Un sito del Pleistocene medio iniziale nel Bacino di Venosa, Museo Pigorini, Roma, Edizioni Osanna, Venosa, 1999.

Piperno, M., Mallegni, F., and Yokoyama, Y.: Découverte d'un fémur humain dans les niveaux acheuléens de Notarchrico (Venosa-Basilicata), C. R. Acad. Sci. II, 311, 1097-1102, 1990.

Radmilli, A. M. and Boschian, G.: Gli scavi a Castel di Guido. Il più antico giacimento di cacciatori nell'Agro Romano, ETS, Pisa, 1996.

Raia, P., Piras, P., and Kotsakis, T.: Turnover pulse or Red Queen? Evidence from the large mammal communities during the PlioPleistocene of Italy, Palaeogeogr. Palaeocl., 221, 293-312, 2005.

Rufo, M. A., Minelli, A., and Peretto, C.: L'industrie en calcaire du site Paléolithique d'Isernia la Pineta: un modèle interprétatif de stratégie comportementale, L'Anthropologie, 113, 78-95, 2009.
Russo Ermolli, E.: Analyse pollinique de la succession lacustre pléistocène du Vallo di Diano (Campani, Italie), Ann. Soc. Belg. Geol., 117, 333-354, 1994.

Russo Ermolli, E., Sardella, R., Di Maio, G., Petronio, C., and Santangelo, N.: Pollen and mammals from the late Early Pleistocene site of Saticula (Sant'Agata de' Goti, Benevento, Italy), Quatern. Int., 225, 128-137, 2010a.

Russo Ermolli, E., Aucelli, P. P. C., Di Rollo, A., Mattei, A., Petrosino, P., Porreca, M., and Rosskopf, C.: An intergrated stratigraphical approach to the late Middle Pleistocene succession of the Sessano lacustrine basin (Molise, Italy), Quatern. Int., 225, 114-127, 2010b.

Sardella, R., Palombo, M. R., Petronio, C., Bedetti, C., and Pavia, M.: The early Middle Pleistocene large mammal faunas of Italy: An overview, Quatern. Int., 149, 104-109, 2006.

Scaillet, S., Vita-Scaillet, G., and Guillou, H.: Oldest human footprints dated by Ar/Ar, Earth Planet. Sc. Lett., 275, 320-325, 2008.

Schattner, U. and Lazar, M.: Subduction, collision and initiation of hominin dispersal, Quaternary Sci. Rev., 28, 1820-1824, 2009.

Segre, A. G. and Ascenzi,, A.: Fontana Ranuccio: Italy's earliest Middle Pleistocene hominid site, Curr. Anthropol., 25, 230-233, 1984.

Segre Naldini, E., Muttoni, G., Parenti, F., Scardia, G., and Segre, A. G.: Nouvelles recherches dans le bassin Plio-Pléistocène d'Anagni (Latium méridional, Italie), L'Anthropologie, 113, 6677, 2009.

Shao, Q., Bahain, J.-J., Falguères, C., Peretto, C., Arzarello, M., Minelli, A., Thun Hohenstein, U., Dolo, J.-M., Garcia, T., Frank, N., and Douville, E.: New ESR/U-series data for the early Middle Pleistocene site of Isernia la Pineta, Italy, Radiat. Meas., 46, 847852, 2011.

Suc, J.-P., Bertini, A., Combourieu-Nebout, N., Diniz, F., Leroy, S. A. G., Russo-Ermolli, E., Zheng, Z., Bessais, E., and Ferrier, J.: Structure of West Mediterranean vegetation and climate since 5.3 ma, Acta Zool. Cracov., 38, 3-16, 1995.

Thun Hohenstein, U., Malerba, G., Giacobini, G., and Peretto, C.: Bone surface micromorphological study of the faunal remains from the Lower Palaeolithic site of Isernia La Pineta (Molise, Italy), BAR Int. Ser. 1272, Actes du XIV Congrès de l'Union Internationale des Sciences Préhistoriques et Protohistoriques, Oxford, 123-127, 2004.

Thun Hohenstein, U., Di Nucci, A., and Moigne, A.-M.: Mode de vie à Isernia La Pineta (Molise, Italie), Stratégie d'exploitation du Bison schoetensacki par les groupes humains au Paléolithique inférieur, L'Anthropologie, 113, 96-110, 2009.

Vekua, A., Lordkipanidze, D., Rightmire, G. P., Agustí, J., Ferring, R., Maisuradze, G., and Zollikofer, C.: A new skull of early Homo from Dmanisi, Georgia, Science, 297, 85-89, 2002. 